\title{
The implementation of smart trash as smart environment concept
}

\author{
Henita Rahmayanti ${ }^{1,}$, Vina Oktaviani ${ }^{2}$, and Yusuf Syani ${ }^{3}$ \\ ${ }^{1}$ Transportation Program, Civil Engineering, Faculty of Engineering, State University of Jakarta, \\ Rawamangun, Indonesia \\ ${ }^{2}$ Informatics Education Studies Program, Electrical Engineering, Faculty of Engineering, State \\ University of Jakarta, Rawamangun, Indonesia \\ ${ }^{3}$ Electronics Engineering Vocational and Education Program, Electrical Engineering, Faculty of \\ Engineering, State University of Jakarta, Rawamangun, Indonesia
}

\begin{abstract}
One of the efforts to improve the quality of urban environment is smart environment concept that has become one of six of smart city indicators such as smart government, smart economy, smart people, smart mobility, and smart living. Smart environment means an environment that provides comfort, resources, physical and nonphysical beauty, and visual for the people, also students in their schools. This research aimed to apply the concept of smart trash bin in schools. This smart trash bin that detects rubbish based on rubbish group (plastic and metal). In addition, the smart trash bin has a function as education for the students as well. It has explanation about knowledge and how to use the trash bin so the students have awareness to keep environment clean and beauty. The research used Research and Development method from Borg and Gall model. The target of this research was the students in elementary school. The final result of this smart trash bin was a feasibility test product. There will be a test for the students using questionnaire. So that this smart trash bin is effective to improve the knowledge of students about rubbish.
\end{abstract}

\section{Introduction}

Smart city is a Smart City concept which can help the citizens to managing the available resource with efficient and give the right information to citizens or institution while doing their work or to anticipate the previous unpredict incident. One of the efforts to improve urban environmental quality is the Smart Environment concept. The Smart Environment concept is one of the 6 Smart City indicators, namely Smart Governance, Smart Economy, Smart People, Smart Mobility, and Smart Living. Smart Environment means the environment can give comfort, sustainability of resources, physical and non-physical beauty, visual or not, for the community, public or existing school institutions. According to the law on spatial planning, requiring $30 \%$ of urban land must be functioned for green open spaces both private and public. A clean, orderly environment is an example of a smart environment.

\footnotetext{
*Corresponding author: henita.rahmayanti@unj.ac.id
} 
Smart environment is an environment that is supported by the existence of technology which is growing rapidly [1]. Smart environtment is a small world where different types of smart devices are continuously working to make lives more comfortable [2]. Distinguishes three types of smart environments: 1) virtual computing environment, 2) physical environment, and 3) human environment.

At this time environmental problems have become a major problem for each city. In dealing with increasing environmental problems, conservation efforts can be carried out by providing education. Education about the environment aims not only to improve science but also to change positive behavior towards the environment into a habit $[3,4]$. Environmental education that is applied at an early age, both through formal education and informal education, is a strategic step to change the behavior and attitudes of children as young people who will replace the older generation $[5,6]$. This is done so that children can better understand and care about the importance of the environment to support the survival of living things. So that the concept of smart environment in the application of smart city can run effectively.

One of the smart environment applications in the environment is smart trash. Smart trash is a smart garbage box that detects waste based on a group of waste, namely metal and plastic waste. Smart trash will be a means of education for children in understanding the types of garbage. The development of smart trash in order and in accordance with smart environment concept in smart city. The outcome of the investigations resulted in smart trash in ways that could be a goal of sustainable development in used as environment learning. This chapter will conclude that the smart traps are used as environment learning for kindergarten.

\section{Methods and equipments}

\subsection{Equipment}

This research object is students of TK Labschool.

\subsection{Methods}

The method used in this study is the method of RnD development by Borg and Gall :

1. Research and data collection which includes needs measurement, literature study, and small-scale research. Preliminary study phase, including: a) Analysis of user needs related to products of concern; b) Literature study, namely reviewing the theory and relevant research results; c) Initial survey of the research location to find out the profile and possibilities if the development model is applied.

2. Planning, namely preparing a research plan, including the abilities needed in conducting research, formulating the objectives to be achieved, making a design or research steps, and planning the possibility of testing in a limited scope. The research planning phase includes: a) Formulating research objectives; b) Estimating funds, energy and time; c) Formulate researcher qualifications and forms of participation.

3. Develop Preliminary Form of Product. The development of the product draft is conducted to determine the research facilities and infrastructure needed during the research and development process and determine the job descriptions of the parties involved in the research.

4. Preliminary field testing. Preliminary field trials or limited trials. During the preliminary field trials observations, interviews, and questionnaires were conducted. The purpose of this initial trial is to get a qualitative evaluation of the product being developed.

5. Revise the main product (main product revision). The main product revision was carried 
out based on the findings in the initial field trial.

6. Main field Testing. Quantitative data on understanding children before and after using the media provided.

7. Improvement of operational products (operational product revision). Improving operational products based on findings in the main field trials.

8. Operational field testing. Testing is done through questionnaires, observation interviews, and others.

9. Final Product Revision. The completion of the final product was carried out based on the findings in the operational field trial.

10. Dissemination and implementation. Make product reports at professional meetings and publish in journals, collaborate with publishers, monitor distribution for quality control.

Data collection techniques used in this study are:

1. Observation Method. Observations made are by making direct observations to the intended school.

2. Interview Method. Interviews were conducted with teachers in schools to obtain information about the initial picture of children's understanding of the material to be delivered.

3. Questionnaire method. Forms of questionnaires in the form of a number of written questions to obtain the information needed. Questionnaires will be given to respondents to be seen from the results of understanding obtained after the media is given.

4. Documentation Method. Conducted to collect research data.

Instrument of collecting data that is done in the research consists of:

1. Interview Guidelines. Interview guidelines are used to analyze research needs with teachers as respondents.

2. Observation Guidelines. Observation guidelines are used to analyze research subjects with direct observation of the knowledge of kindergarten children.

3. Questionnaire. Questionnaires are used to see how much influence the media has with the level of understanding of kindergarten children.

Data analysis techniques in this study with Data Analysis Results of Questionnaire of Respondents. The calculation of the respondent's test uses the Guttman scale with the following formula:

$$
\begin{aligned}
& x=\frac{\text { The total number of children assessed }}{\text { Perfect Assessment }} \times 100 \% \\
& x=\text { Percentage of Score }
\end{aligned}
$$

Based on the formula, the results of "decent / good" smart trash media will be used as a tool for kindergarten children to understand the concept of waste in realizing smart city if the feasibility presentation reaches $>75 \%$. On the contrary it is said "not feasible / not good" if the presentation of feasibility is $\leq 75 \%$.

\section{Result}

An Implementation of Smart Trash as Smart Environment Concept, are: 
1. Concept of material. The concept of the material used is about the smart garbage box which is a means of education for early childhood in understanding various types of waste based on the category of plastic waste and metal waste.

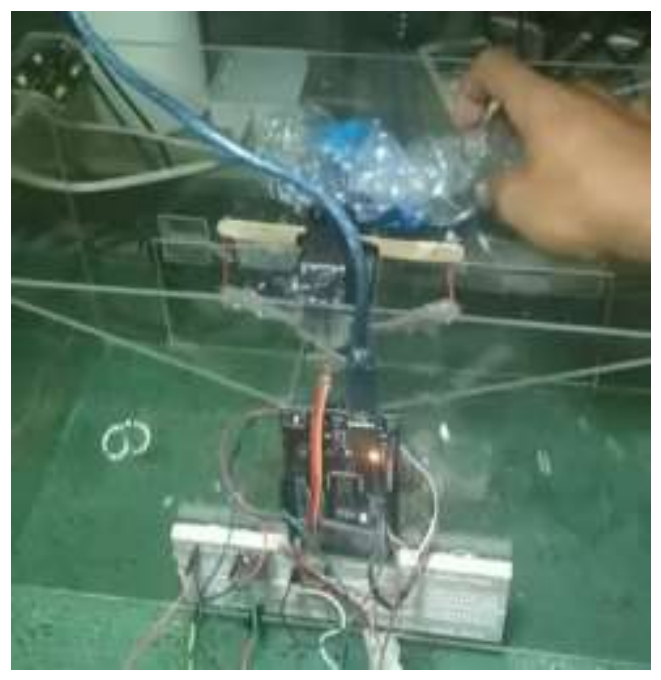

Fig. 1. Children test with the smart garbage box.

2. The results of the field trial were carried out three times in the form of observations made by asking directly the TK Labschool students after using smart trash as an aids media in learning about the smart trash concept in the application of smart environment. Three field trials consisted of:

a. Initial field trial. The initial field trial consisted of four respondents. Observation results from the initial field trials obtained high presentation results, namely $90 \%$ included in the feasible category.

b. Main field trial. The main field trial consisted of six respondents. The results of observations from the main field trials obtained high presentation results but under the results of the initial field trials which amounted to $85 \%$, but still in the feasible category.

c. Operational field trial. The operational field trial consisted of ten respondents. In this trial observations were made after the effectiveness test. Based on the results of the effectiveness test results obtained $88.4 \%$, which means having a high product effectiveness value. The results of observations from operational field trials obtained a high percentage of $95 \%$ and included in the feasible category.

\section{Conclusions}

Smart trash can be effective to increase the ability to improve the cognitive abilities of early childhood in understanding the concept of waste. Through smart trash can, early childhood can distinguish types of waste based on the category of plastic waste and metal waste. Based on the results obtained, the data obtained is that the smart trash can get the average value of the feasibility of $90 \%$. Based on the level of product effectiveness, smart trash has a value of $88.4 \%$, which means that smart trash has a high value of product effectiveness. So it can be concluded that smart trash can be a viable tool for early childhood in increasing early childhood knowledge in schools about the material types of 
waste so that the application of smart environment can be applied.

\section{References}

1. D. Cook, S. Das, Smart Environments: Technology, Protocols and Applications (Wiley-Interscience, 2005)

2. S. Poslad, Ubiquitous Computing Smart Devices, Smart Environments and Smart Interaction (Wiley, 2009)

3. L.G. Anthopoulas, A. Vakali, Urban Planning and Smart Cities: Interrelations and Reciprocities. In Alvarez F. et al (Eds.), The Future Internet, 7281, 178-189 (2012)

4. Bolivar, P.R. Manuel, Transforming City Governments for Successful Smart Cities. In Bolivar, Manuel P.R (Eds.) (Springer, Cham, 2015)

5. Chourabi, H., Nam, T., Walker, S., Gil-Garcia, J. R., Mellouli, S., Nahon, K., Pardo, T.A., \& Scholl, H.J. Understanding smart cities: An integrative framework. Proceedings of the 45th HICSS, IEEE, 2289-2297 (2012)

6. B. Van Heur, Geography Compass 4, 12, 1713-1724 (2010) 